Original Paper

doi $10.15826 /$ recon.2021.7.1.005

UDC 339.5, 339.9

JEL Q14, Q17, F14

\title{
Prospects for Chinese-Russian cooperation in the dairy sector
}

\section{Q. Chen}

Institute of Russia of the Academy of Social Sciences of Heilongjiang Province, Harbin, China; 284748191@qq.com

\section{ABSTRACT}

Relevance. The COVID-19 pandemic is a new challenge facing humanity, which has already caused serious damage to the global economy. In particular, international cooperation has faced somewhat unprecedented challenges. In the post-pandemic era, it is extremely important to study the state of the dairy sector in China in order to find a way to develop cooperation between the People's Republic of China and the Russian Federation in this field. Research objective. To analyse the state of China's dairy sector in the post-pandemic period, taking into account the trend of recovery, as well as to identify the priority areas and interaction directions in the dairy sector between China and the Russian Federation. Data and Methods. The research was conducted using the methods of comparative analysis, focusing mainly on quantitative and qualitative indicators. The conditions for the interaction of the dairy sector between China and the Russian Federation were analysed. Results. It is shown that, at present, the Chinese-Russian interaction in the dairy sector includes four aspects: trade in dairy products, experience exchange, investment cooperation and interaction at the governmental level. Trade in dairy products and the exchange of experience and technologies in the dairy sector are developing steadily, supported by increased interaction at the state level. Conclusions. The Chinese-Russian cooperation in the dairy sector is experiencing some difficulties; however, the common interest of both countries in dairy production and the strong support of both governments ensure excellent prospects for achieving mutual benefits and high performance.

\author{
KEY WORDS \\ Russia, China, COVID-19 \\ pandemic, dairy sector, \\ consumption structure, raw \\ milk imports, 'double cycle' \\ economic model, trade in dairy \\ products, investment interaction, \\ cooperation directions
}

\section{FOR CITATION}

Chen, Q. (2021) Prospects for Chinese-Russian cooperation in the dairy sector. R-economy, 7(1), 52-60. doi: $10.15826 /$ recon.2021.7.1.005.

\section{Перспективы китайско-российского сотрудничества в молочной отрасли}

\section{Ц. Чэнь}

Институт России Академии общественных наук провиниии Хэйлунизян, Харбин, Китай; 284748191@qq.com

\begin{abstract}
АННОТАЦИЯ
Актуальность. Пандемия COVID-19 - это новый вызов, стоящий перед человечеством, который уже нанес серьезный ущерб мировой экономике. В частности, международное сотрудничество столкнулось с беспрецедентными проблемами. В постпандемическую эпоху чрезвычайно важно изучить состояние молочного сектора в Китае, чтобы найти способ развития сотрудничества между Китайской Народной Республикой и Российской Федерацией в этой области. Цель исследования. Проанализировать состояние молочного сектора Китая в постпандемический период с учетом тенденции восстановления, а также определить приоритетные направления взаимодействия в молочном секторе между Китаем и Российской Федерацией. Данные и методы. Исследование проводилось методами сравнительного анализа, уделяя основное внимание количественным и качественным показателям. Проанализированы условия взаимодействия в молочной отрасли между Китаем и Российской Федерацией. Результаты. Показано, что в настоящее время китайско-российское взаимодействие в молочной отрасли включает четыре аспекта: торговля молочными продуктами, обмен опытом, инвестиционное сотрудничество и взаимодействие на государственном уровне. Торговля молочными продуктами и обмен опытом и технологиями в молочном секторе стабильно развиваются, чему способствует усиление взаимодействия на государственном уровне. Выводы. Китайско-российское сотрудничество в молочной отрасли испытывает определенные трудности; однако общий интерес обеих стран к производству молочной продукции и сильная поддержка обоих правительств обеспечивают прекрасные перспективы для достижения взаимной выгоды и высоких показателей.

КЛЮЧЕВЫЕ СЛОВА

Россия, Китай, пандемия COVID-19, молочный сектор, структура потребления, импорт сырого молока, экономическая модель «двойного цикла», торговля молочными продуктами, инвестиционное взаимодействие, направления сотрудничества

\section{ДЛЯ ЦИТИРОВАНИЯ}

Chen, Q. (2021) Prospects for Chinese-Russian cooperation in the dairy sector. R-economy, 7(1), 52-60. doi: 10.15826/ recon.2021.7.1.005. 


\section{Introduction}

About 18 years passed from the incident of SARS (atypical pneumonia) in 2002 to the spread of COVID-19 in early 2020. Experience shows that infectious diseases, epizootics among animals (Ran et al., 2019), epidemics and pandemics among humans used to arise in the past and will continue to exist in the future. At the beginning of the spread of the COVID-19 pandemic, China's dairy sector, similar to other industries, faced serious difficulties. However, COVID-19 has had a positive impact on dairy production to some extent, since anti-epidemic and nutrition experts recommended the population to consume more milk during the pandemic to improve immunity. The Chinese government also published a document stating that "the prevention and control of the epidemic must ensure a daily consumption of 300 grams of milk", which has had a good publicity effect in promoting milk consumption by households throughout the country (Hou, 2021). Due to the recovery of the domestic macroeconomic situation in China, the dairy market is currently recovering at an accelerated rate. Economic ties with neighbouring states, including Russia, are also being gradually restored. As China's most important neighbour, Russia has excellent natural resources, vast lands, abundant water resources and strong agricultural production potential, which is an important incentive for dairy cooperation (Li Zhanhui, 2014).

The purpose of this paper is to analyse the state of the People Republic of China's (PRC) dairy sector, priority areas and interaction possibilities in the dairy sector between the PRC and the Russian Federation. To achieve this goal, a number of tasks were formulated. First, it is important to investigate the dynamics of milk production indicators, imports of dairy products, milk procurement price in the PRC against the background of the recovery of the dairy sector, as well as transformations in the structure of dairy production consumption and increasing openness to external markets in the post-pandemic period. Second, the scale of trade in dairy products should be clarified in order to identify promising investment areas in the dairy sector between the PRC and the Russian Federation. Third, directions for promoting dairy cooperation between both countries should be outlined.

\section{Data and Methods}

This research was conducted using comparative methods, with a focus on both quantitative and qualitative indicators, in order to reveal similarities and differences in the interaction approaches applied by China and Russia in the dairy sector.

First, the state of the dairy sector in China was assessed, in particular, milk production indicators, the dynamics and structure of consumption of dairy products, imports of dairy products, raw milk procurement prices. Further, the state of Chinese-Russian cooperation in the dairy sector, including trade in dairy products, sectoral exchanges, corporate investment cooperation and interaction at the state level, was investigated. Finally, the current trends in the Chinese-Russian cooperation in the dairy sector were outlined by discussing the advantages, disadvantages, opportunities, threats and possible cooperation directions between the two countries.

Statistical data from the official websites of the National Bureau of Statistics of the PRC and the Customs of the PRC was used.

\section{Literature Review}

It should be noted that the topic of cooperation in the dairy sector between the PRC and the Russian Federation attracts the attention of many scholars and specialists. The dairy sector is closely related not only to animal husbandry and processing, but also to the income of manufacturers and health of consumers (Adegbola, Geoffrey, 2020). Experts in this field note that the dairy sector is an important industry related to food safety, as well as a strategic industry for agricultural modernization and coordinated development of primary, secondary and tertiary industries $(\mathrm{Ma}$ Youxiang, 2018). Sun Yongjian (2020) concluded that, over the past 20 years, the quality of dairy products in the PRC has improved significantly, allowing the quality of raw milk produced by large farmers to reach the level of developed countries. According to Li Shengli, Yao Kun and Cao Zhijun (2020), China has now become the world's largest importer of dairy products; therefore, a stable international trade and investment environment is vital for the efficient and steady development of China's dairy sector.

Nevertheless, as noted by Wang Dongjie (2020), under the influence of the coronavirus infection, transport and logistics in the world are experiencing difficulties, which significantly limit the volume of China's dairy imports. Liu Changquan and Han Lei (2021) foresaw that China's economic growth rate in 2021 would still remain uncertain and influenced by such factors, as the 
domestic and foreign pandemic trends, as well as international economic and trade relations. Consequently, the growth rate of consumer demand for dairy products in China is likely to slow down.

Sun Jinglun, Guo Yanzhi and Peng Hua (2020) investigated the development of the Russian dairy sector and came to the conclusion that, with the support of a governmental policy, the structure of production in the dairy sector is being continuously optimized. Cong Shufeng, Li Xueyuan and Li Meng (2020) conducted a study on agricultural trade between Heilongjiang province and Russia in the face of the new coronavirus pandemic, particularly in the context of cooperation in agricultural trade at the local level between the two countries. It was found that the Far East would likely to become one of the priority regions of the Russian dairy industry. Other researchers argue that cooperation in the dairy sector between the PRC and the Russian Federation can be based on technology exchange and increased investments (Sun Jinglun, Guo Yanzhi \& Peng Hua, 2020). When analysing the international experience of cooperation in the dairy sector, Wei Yanjiao and Zhu Jing (2019) provided some examples of successful interaction between developed countries, which can serve as a reference point for Chinese-Russian cooperation in the dairy sector.

Although the authors of the abovementioned studies have elucidated the state of the dairy sector in the PRC, the development of the Russian dairy sector and various questions of agricultural interaction between the PRC and the Russian Federation, including between regions in recent years, there is little information on the Chinese-Russian cooperation in the dairy sector in the post-pandemic period.

\section{Results}

With the support of both governments, the PRC and the Russian Federation signed a number of agreements on deepening cooperation in the dairy sector, which confirms the intention to strengthen the interaction between Chinese and Russian companies. To identify the prospects for cooperation, both parties need to analyse the advantages and disadvantages, as well as the risks of Chinese-Russian cooperation in the dairy sector.

\section{Post-pandemic analysis of China's dairy sector}

The recovery of the macroeconomic situation in China has created a favourable environment for the development of the dairy sector. Since the outbreak of the new coronavirus infection at the end of 2020, China's economy has moved ahead in terms of renewed growth, compared to developed and emerging economies. China has become the only country in the world, the economy of which has achieved positive growth. Thus, the rate of economic growth in China in the first three quarters ranged from $-6.8 \%$ to $3.2 \%$, equalling $4.9 \%{ }^{1}$ compared to the same period of the previous year.

On May 14, 2020, at a meeting of the Standing Committee of the Politburo of the CPC Central Committee, it was proposed for the first time to accelerate the construction of a new development model seeking to expand the domestic demand, increasing consumption and improving the population's living standards ${ }^{2}$. In this regard, the Chinese government pays special attention to the development of the dairy sector. According to incomplete statistics from the PRC Dairy Association, from January to April 2020, the central government and relevant ministries and commissions issued a total of 72 articles related to the dairy sector (Yu Du, 2020). Let us consider the factors that substantiate the significant role of the dairy sector in the PRC.

\section{Milk production growth peaks in five years}

Since 2019, against the signs of revival in the dairy sector, China has been demonstrating a growing trend in the number of high-quality milk producers. In addition, small and medium-sized dairy farms are currently undergoing modernization, thus intensifying breeding activities. All this contributes to a sustainable growth of dairy production in China (Wang Dongjie, 2020). The annual milk production is estimated to be 33.05 million tons, which comprises a $4.0 \%$ increase as compared to the previous year. Among this volume, the production of cow milk amounted to 32.01 million tons, which exceeded the previous year's output by $4.1 \%$ (Figure 1). As a result, the growth rate has reached a new maximum over the past five years. The share of large dairy farms with more than 100 cows is estimated to be $64.0 \%$ (Sun Yongjian, 2020).

\footnotetext{
${ }^{1}$ Economic data for the first three quarters of 2020, China Government Network. http://www.gov.cn/zhuanti/2020sjdjjsj/index.htm (date of access: December, 2020)

${ }^{2}$ Liu He, Accelerate the construction of a new development pattern in which the domestic big cycle is the main body and the domestic and international double cycles promote each other. People's Daily. 2020-11-25. Available at: http://www.npc. gov.cn/npc/c30834/202011/8b3c09a4d4aa4d22a97decd22dc2b0c6.shtml (In Chinese)
} 


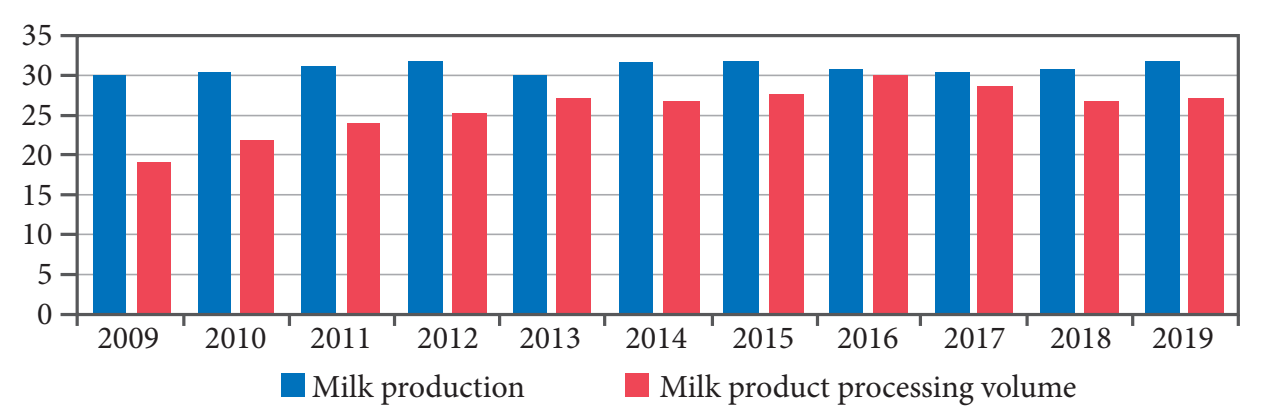

Figure 1. China's milk production and milk product processing volume change in 2009-2019. Unit: million tons Source: National Bureau of Statistics of China. Retrieved from: https://www.sohu.com/a/381307223 728793 (date of access: December 8, 2020)

The processing of dairy products in China continues to grow. This particularly regards liquid milk processing, which grew faster than that of dry dairy products in 2019. According to the $\mathrm{Na}$ tional Bureau of Statistics of the People's Republic of China, the national dairy processing volume was 27.194 million tons in 2019, exceeding that in the previous year by $5.6 \%$ (Guo Hongxia \& Feng Ce, 2020). In terms of individual provinces, Hebei ranked first in terms of dairy processing volume. This province provides $13.1 \%$ of the country's total dairy production, followed by Inner Mongolia (10.6\%), Shandong (8.0\%), Henan (7.3\%), and Heilongjiang (6.0\%) (Wang Dian, Zhao Xianghao, $\&$ Wang Xiaoqiong, 2019). The top 10 provinces together account for $67.3 \%$ of the country's total dairy processing (Li Jiaxi, 2020). During the spread of the COVID-19 pandemic and in the post-pandemic period, the volume of liquid milk processing continues to demonstrate a positive growth rate. From January to September 2020, the volume of liquid milk production amounted to 19.06 million tons, which is an increase of $1.60 \%$ compared to the same period in 2019. Conversely, the production of dry milk slightly decreased, amounting to 1.321 million tons during the January-September 2020 period and being 5.33\% lower compared to the same period in 2019. It should be noted that the production of both liquid milk and dry milk increased significantly in September during the post-pandemic period (Zhang Caihong \& Ren Qifang, 2020).

\section{Consumption and import of dairy products are growing steadily}

Along with improving the quality and safety of dairy products processed in China, consumer confidence in domestic dairy products continues to grow. Many Chinese people develop milk-drinking habits, which contributes to a steady increase in the total volume of dairy products (Song Liang, \& Li Yang, 2020). Thus, the annual consumption of raw milk in China per capita was approximately 33.2 kilolitres and 35.8 kilolitres in 2018 and 2019, respectively ${ }^{3}$.

According to the statistical data provided by the General Administration of Customs of China, in 2020, China imported 3.28 million tons of dairy products (including powdered infant blends), which exceeded the previous year's amount by $10.4 \%$. The total expenses on imports comprised $\$ 11.71$ billion, which exceeded the previous year's spending by $5.2 \%$. In terms of types of dairy imports, whey and butter grew rapidly in 2020, fresh milk and cheese also showed some growth (Table 1).

Table 1

Imports of dairy products by the PRC in 2020

\begin{tabular}{|c|c|c|c|c|}
\hline \multirow[b]{2}{*}{ Products } & \multicolumn{2}{|c|}{ Imports volume } & \multicolumn{2}{|c|}{ Imports value } \\
\hline & $\begin{array}{c}\text { Total } \\
\text { volume, } \\
\text { (million } \\
\text { tons) }\end{array}$ & $\begin{array}{c}\text { Growth } \\
\text { compared } \\
\text { to } 2019 \text {, } \\
\%\end{array}$ & $\begin{array}{c}\text { Total } \\
\text { value, } \\
\text { billion } \\
\text { USD }\end{array}$ & $\begin{array}{c}\text { Growth } \\
\text { compared } \\
\text { to } 2019 \text {, } \\
\%\end{array}$ \\
\hline Dairy products & 3.28 & 10.4 & 11.71 & 5.2 \\
\hline milk & 1.07 & 16 & 1.37 & 17.8 \\
\hline fresh milk & 1.04 & 16.8 & 1.31 & 18.9 \\
\hline yoghurts & 0.032 & -4.9 & 0.06 & -1.6 \\
\hline Dry dairy products & 2.21 & 7.8 & 10.34 & 3.8 \\
\hline powdered milk & 0.979 & -3.5 & 3.29 & 5.4 \\
\hline whey & 0.626 & 38.2 & 0.82 & 34.9 \\
\hline cheese & 0.129 & 12.5 & 0.59 & 13.1 \\
\hline butter & 0.116 & 35.2 & 0.55 & 17.1 \\
\hline condensed milk & 0.024 & -31.6 & 0.04 & -27.5 \\
\hline $\begin{array}{l}\text { powdered milk for } \\
\text { babies }\end{array}$ & 0.335 & -3.0 & 5.05 & -2.7 \\
\hline
\end{tabular}

Source: National Bureau of Statistics of China. Retrieved from: http://nk.boyar.cn/article/1073956.html (date of access: December 8, 2020)

${ }^{3}$ Annual consumption of raw milk in the PRC per capita reaches $35.8 \mathrm{~kg}$. Available at: https://baijiahao.baidu.

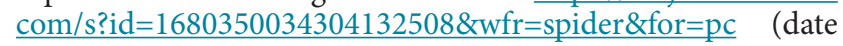
of access: December 8, 2020) 
In 2020, the main source countries of imports to the PRC were New Zealand, the USA and Australia, which accounted for $45.3 \%, 13.7 \%$ and $6.6 \%$ of the total imports of dairy products, respectively. Among the three leading countries in terms of imports value, New Zealand ranked first, Australia - second, and Germany - third (Figure 2).

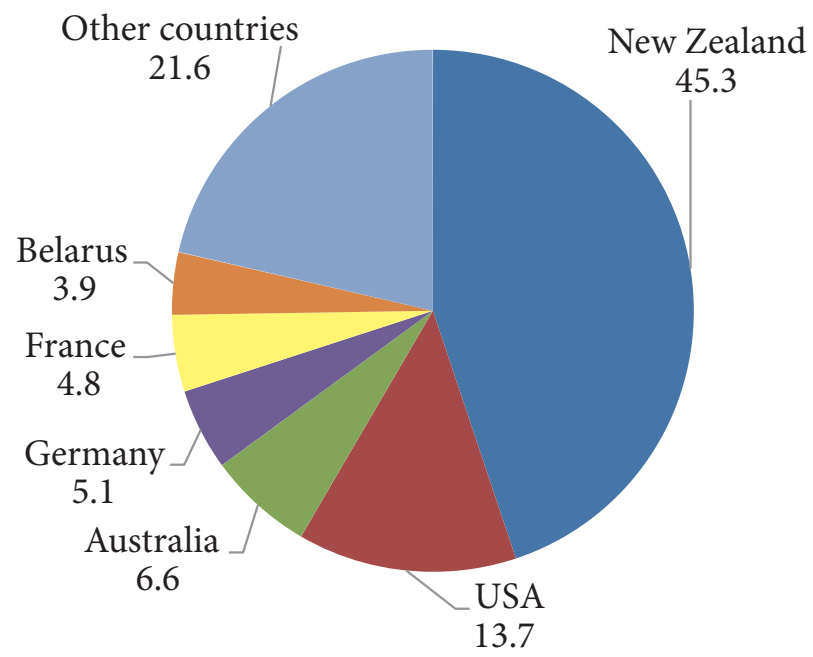

Figure 2. Proportion of total imports (\%)

Source: China Customs. Retrieved from: http://nk.boyar. cn/article/1102345.html (date of access: December 8, 2020)

The procurement price of raw milk reached a five-year maximum; the retail price of fresh milk and powdered milk rose significantly

Under the influence of a high consumer demand for dairy products and rising production costs, fresh milk procurement prices are growing steadily. According to the Ministry of Agriculture and Rural Affairs of the PRC, the average fresh milk procurement price was 3.65 yuan $/ \mathrm{kg}$ in 2019, which exceeded that in the previous year by $5.5 \%$ and reaching a maximum over the past five years. Due to a variety of factors, such as an increase in the procurement price of raw milk, the restoration of Chinese confidence in domestic powdered milk, and a narrowing quality gap between domestic and foreign powdered milk, the average retail price of domestic three-stage baby powdered milk in- creased by $10.8 \%$, which far exceeds the growth of similar imported milk price (Table 2).

\section{State of cooperation between the PRC and Russia in the dairy sector}

As neighbouring countries, China and Russia maintain trade exchange, particularly in the fields of energy, minerals and manufactured goods. At the same time, the share of trade in agricultural products has so far been relatively low, decreasing to $3.98 \%$ of the total trade volume in 2013 (Yang Fengmin \& Ding Jianjiang, 2015). With the advancement of the Belt and Road Initiative, dairy cooperation between China and Russia began to expand (Li Zhanhui, 2014).

\section{Trade in dairy products}

From 1999 to 2018, the volume of trade in dairy products between China and Russia was relatively small; in some years (2001-2002, 20102011), there was virtually no trade (Figure 3). After 2014, under the influence of trade sanctions from the EU, Russia began to penetrate the Chinese dairy market rather actively. Since then, the volume of imports of Russian dairy products to China had been increasing steadily and peaked at $\$ 979$ thousand in 2018. With the purpose of expanding the scale of imports of dairy products from Russia, the Federal Service for Veterinary and Phytosanitary Surveillance of Russia and the General Administration of Customs of China signed a protocol on mutual deliveries of dairy products between Russia and China at the end of 2018. Initially, the Chinese party approved only ten Russian dairy plants; however, already in April 2019, the list of Russian producers entitled to supply dairy products to China had been expanded to $33^{4}$. In this regard, the volume of whey imported from Russia to China increased significantly in 2019.

\footnotetext{
${ }^{4}$ Russian dairies to file joint lawsuit against Chinese firm. Retrieved from: https://ria.ru/20190617/1555618512.html (date of access: December, 2020)
}

Dynamics of prices for raw milk, fresh milk and powdered milk in the PRC in 2018-2019, yuan/kg

\begin{tabular}{|l|c|c|c|c|c|c|c|}
\hline \multirow{2}{*}{ Year } & \multirow{2}{*}{ Raw milk } & \multicolumn{3}{c|}{ Fresh milk } & \multicolumn{3}{c|}{ Powdered milk } \\
\cline { 3 - 8 } & & Average & In packs & In boxes & Average & Local & Imported \\
\hline 2019 & 3.65 & 10.73 & 9.86 & 11.61 & 208.92 & 185.87 & 231.96 \\
\hline 2018 & 3.46 & 10.59 & 9.73 & 11.45 & 198.17 & 167.70 & 228.64 \\
\hline Percent change, \% & 5.50 & 1.3 & 1.3 & 1.3 & 5.4 & 10.8 & 1.5 \\
\hline
\end{tabular}

Source: National Bureau of Statistics of China. Retrieved from: http://nk.boyar.cn/article/1073956.html (date of access: December 13, 2020) 


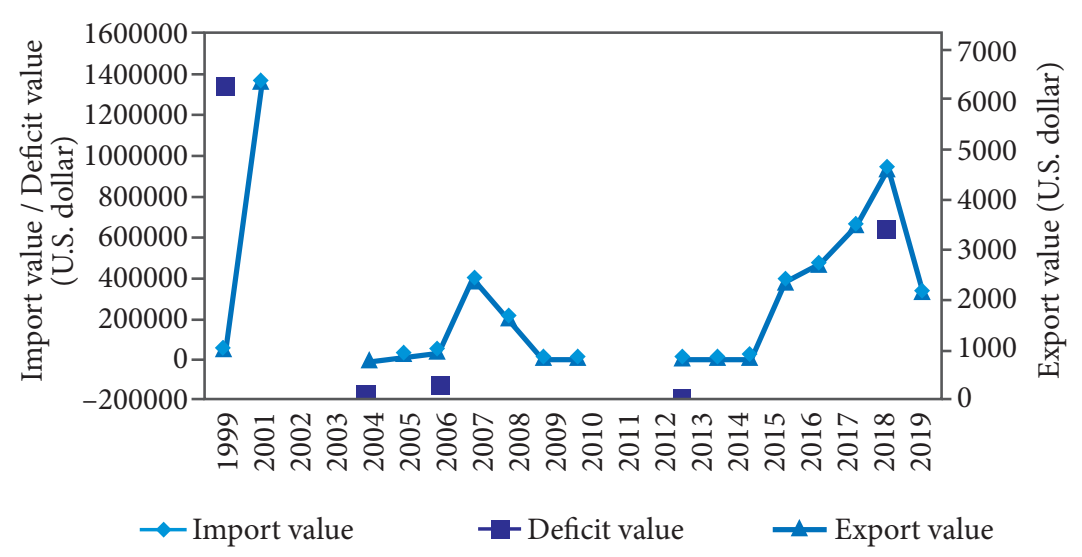

Figure 3. China's import of Russian dairy products trade deficit situation Source: United Nations Commodity Trade Statistics Database

http://cdmd.cnki.com.cn/Article/CDMD-10213-1018894762.htm (date of access: December 8, 2020)

\section{Investment cooperation of dairy enterprises}

Since active cooperation between China and Russia in the dairy sector is at its onset, the current volume of trade in dairy products is still relatively small. In October 2015, the Chinese company Zhongding Dairy Farming put forward a plan to invest 1.5 billion yuan in the joint construction of a Chinese-Russian dairy complex in the Primorye Territory and a demonstration area for dairy products of both countries. In 2019, Zhongding Dairy Farming became the owner of 30 thousand hectares of land, a large pasture and a railway freight station in the Primorye Territory. The company has built a logistics platform for internal and external trade exchanges and a processing plant with a daily output of 500 tons of dairy products, thereby creating a strategic framework for the entire production chain of agriculture, animal husbandry and the dairy sector. This enterprise has become a benchmark for Chinese-Russian cooperation in the field of agriculture and animal husbandry.

\section{Cooperation at the governmental level}

With the implementation of the Belt and Road Initiative and the construction of the China-Mongolia-Russia economic corridor, strategic cooperation between China and Russia is developing at a high level; the bilateral trade and economic relations have entered the best period in history. In February 2018, China and Russia officially launched a trade cooperation project for the export of dairy cows and the import of milk by the Chinese party. According to the General Administration of Customs of the PRC, on May 26, 2020, the first batch of Russian dairy products officially entered the Chinese market through the border crossing point in Suifenhe. On August 14, the Bureau of Inspection and Quarantine under the General Administration of Customs of the PRC and the Bureau of Veterinary and Phytosanitary Surveillance of the Ministry of Agriculture of the Russian Federation signed "The Trade Agreement on the export of Chinese dairy cows and the import of Russian milk", which has created favourable conditions for raising Chinese cows in Russia and returning fresh milk to China for processing. In addition, during the meeting of the prime ministers of China and Russia in November 2018, the General Customs Administration of the PRC and the Federal Service for Veterinary and Phytosanitary Surveillance of Russia signed the "Protocol on Veterinary and Sanitary Requirements for Mutual Deliveries of Frozen Poultry and Dairy Products between China and Russia", which stipulated the terms of trade in dairy products of both states.

\section{Analysis of the situation of Chinese-Russian dairy cooperation}

Advantages. Currently, the level of self-sufficiency in milk is $85.10 \%$ and $71.10 \%$ in Russia and China, respectively. It is assumed that the consumption of dairy products in China will reach 65 million tons in 2025; therefore, it is required to increase the supply of dairy products by more than 28 million tons compared to 2017. In 2018, in order to attract investments, the Russian government offered to lease 1 million hectares of agricultural land in the Far East to Russian and foreign investors, which aroused the interest of Chinese farmers. Russia can supply agricultural products, including milk, to the large Chinese market. The 
cooperation between the two countries is undoubtedly mutually beneficial. In Russia, the advantage lies in the availability of natural resources, which factor provides lower costs of milk production but contributes to higher competitiveness in the market compared to China. In addition, Russia has one of the strictest agricultural control systems in the world. Crop cultivation complies with the EU standards, which strictly limit the amount and type of pesticides and fertilizers used. Dairy farming in Russia has a guarantee of the high food safety and quality of dairy products supplied to the Chinese market. The Chinese party, in its turs, possesses investment opportunities and advanced technologies. Among the latter are the technologies of dairy farming and dairy processing, which ideally match the excellent natural conditions of the Russian party. Therefore, dairy cooperation is an important channel for realizing additional advantages of the two countries and enhancing commercial significance.

Disadvantages. Despite the fact that China and Russia both have a great potential for expanding cooperation in the dairy sector, there still remain problematic aspects. First, compared to traditional dairy plants in Western countries, Russian producers are yet to make full use of advanced technologies (Zainutdinova, 2017, Zhongming, Nan \& Jun, 2015). In addition, the sanctions imposed on Russia by the European countries and the United States in recent years have extended to foreign investment projects in the Far East, which has a negative impact on investments from Chinese dairy companies to the Far East (Xinye \& Hailong, 2016). Second, the difficulty of expanding trade in dairy products for the two countries lies in the high transport costs in Russia, due to which the profitability of dairy production is relatively low $^{5}$. Third, Russian enterprises are not very familiar with the Chinese dairy market and do not have sufficient experience of cooperation with China. To conquer the Chinese dairy market, Russian dairy producers will have to work hard to meet the aesthetic preferences and tastes of Chinese consumers (Maitiniyazi, Canavari, 2021).

Prospects. In recent years, the leaders of China and Russia have repeatedly met to reach a common understanding of the need to deepen the alignment of the Belt and Road Initiative and the Eurasian Economic Union, as well as to expand co-

${ }^{5}$ Cooperation between China and Russia begins in the Far East. Retrieved from: https://finance.huanqiu.com/article/ 9CaKrnKmLU1.2019-09-11 (date of access: December, 2020) operation in the fields of energy, agriculture, technological innovation and finance. This has laid a solid foundation for the joint promotion of cooperation in the Chinese-Russian dairy sector. Some Russian scholars stressed that the development of the dairy sector in the country requires comprehensive and pragmatic international cooperation (Kuzin, Medvedeva \& Zadumkin, 2018). In 2018, China and Russia reached an agreement on quarantine requirements for the delivery of dairy cows to the Russian party, eliminating any obstacles to such transportation. It can be assumed that, along with a decreasing impact of the novel coronavirus infection on production, cooperation between China and Russia in the dairy sector will deepen and expand.

Given that China has a greater demand for high-quality dairy products, and Russia has a good ecological environment and less pollution, both parties can jointly build plants in the Russian dairy areas and cooperate in dairy production and processing (Hongpeng \& You, 2018). Thus, on-site dairy production can reduce the cost of transporting raw milk, shorten the dairy production cycle and improve the quality of products.

Threats. Chinese-Russian cooperation in the dairy sector has a certain impact on dairy farms (households) in China. Thus, the lower cost of land in Russia resulted in the lower cost of dairy cows; these factors contributed to the lower prices of raw milk in Russia compared to China. In 2018, the price of raw milk was 3.5 and 2.4 yuan $/ \mathrm{kg}$ in China and Russia, respectively. It can be assumed that the import of fresh milk will decrease prices for homemade fresh milk in the Chinese market, thereby affecting the interests of Chinese farms (households). In addition, following the signing of the agreement by both parties on trade in livestock products, live cattle in particular, the risk of animal diseases has risen and epidemic prevention for both parties has intensified. Since product quality and safety are key factors in agricultural trade (Tan et al., 2021), these threats may be damaging for the Chinese-Russian dairy cooperation.

With the development of Chinese-Russian cooperation in the dairy sector and increased volume of trade in livestock products between the two countries, the latent danger of animal diseases will also increase. As a result, the activity aimed at animal disease prevention in both countries will become more challenging (Brunner et al., 2019, Heng, \& Zhengbing, 2010). Under these circumstances, both parties should, without delay, deve- 
lop an effective system for early prevention of animal diseases and a plan for emergency response, thus contributing to the development of mutually beneficial cooperation in the dairy sector.

\section{Conclusions}

The conducted analysis has shown that, despite the significant damage of the novel coronavirus pandemic to the global economy, the imports of dairy products to China have not decreased. This fact indicates prospects for Chinese-Russian cooperation in the dairy sector, in which both parties enjoy specific advantages. Due to strict regulation in the sphere of food safety and quality, Russia can supply high-quality and safe dairy products to the Chinese market. China has the advantage of investment opportunities and advanced technologies in dairy farming and dairy processing. Importantly, these technologies are suitable for Russian natural conditions. The cooperation between the two parties is undoubtedly mutually beneficial. Since 2014, when trade sanctions from the EU were imposed, Russia has started to actively develop the Chinese dairy market, with the volume of imports of Russian dairy products to China steadily increasing. Thus, harnessing the potential of Chinese-Russian dairy cooperation is essential for meeting the growing demand for dairy products in the Chinese consumer market.

In the post-pandemic period, international trade is expected to gradually recover, thus creating favourable conditions for trade and economic cooperation between the PRC and the Russian Federation. Wide opportunities for the development of Chinese-Russian dairy cooperation are also associated its current small scale and the alignment of the Belt and Road Initiative and the Eurasian Economic Union.

\section{References}

Adegbola, T., \& Geoffrey, E. (2020). MILK Symposium Introduction: Dairy production in developing countries. Journal of dairy science, 103(11), 9677-96810. doi: 10.3168/jds.2020-18313.

Brunner, N., Groeger, S., Canelas Raposo, J., Bruckmaier, R.M., \& Gross, J.J. (2019). Prevalence of subclinical ketosis and production diseases in dairy cows in Central and South America, Africa, Asia, Australia, New Zealand, and Eastern Europe. Translational animal science, 3(1), 84-92. doi: 10.1093/tas/txy102.

Cong Shufeng, Li Xueyuan, \& Li Meng (2020). Research on the Upgrade of Heilongjiang Province's Agricultural Products Trade with Russia under the New Crown Epidemic, Financial Theory and Teaching, 6, 54-56. (In Chinese)

Kuzin A., Medvedeva N, Zadumkin K.A., Vakhrusheva V.V. (2018). Development scenarios for Russia's dairy industry. Economic and Social Changes: Facts, Trends, Forecast, 11(6), 73-88. doi: 10.15838/esc.2018.6.60.5.

Guo Hongpeng, \& Wu You (2018). Research on the Development of Sino-Russian Agricultural Cooperation from the Perspective of 'One Belt, One Alliance', Northeast Asia Forum, 27(5), 83-95, (In Chinese)

Guo Hongxia, \& Feng Ce (2020). Talking about the prospects and innovation increment of China's dairy market, Dairy and human, 5, 21-26. (In Chinese)

Hou Junwei (2021) New Cycle of Dairy Industry,New Breakthrough of Growth Analysis of China Dairy Market and Development Trend of 2021 Market in 2020, China Dairy Industry, 2, 2-7. (In Chinese)

Li Jiaxi (2020).Inject farming power into the high-quality development of China's dairy, China Land Reclamation, 10, 18-22. (In Chinese)

Li Shengli, Yao Kun, \& Cao Zhijun (2020). 2019 Dairy Cattle Industry Technology Development Report, China Animal Husbandry Journal, 56(3), 136-144. (In Chinese)

Li Zhanhui (2014). Analysis of the potential for the development of modern large-scale agriculture in the Russian Far East. Frontier Economy and Culture, 10, 22-23. (In Chinese)

Liu Changquan, \& Han Lei (2021). Review of the economic situation of China's dairy industry in 2020 and outlook for 2021, China Animal Husbandry Journal, 4, 38-47. (In Chinese)

Liu Fengming (2019). Analysis on the Product Marketing Strategy of Chinese Dairy Enterprises. Contemporary business, 21, 13-17. (In Chinese)

Lu Xinye, \& Cai Hailong (2016). The adjustment, influence and enlightenment of Russia's agricultural trade policy under the background of economic sanctions, Agricultural Economic Issues, 4, 98-102. (In Chinese) 
Ma Youxiang (2018). Promote high-quality development and accelerate the overall revitalization of the dairy industry. Agricultural Products Market, 9, 41-42. (In Chinese)

Ran, X., Chen, X., Ma, L., Wen, X., Zhai, J., Wang, M., ... \& Ni, H. (2019). A systematic review and meta-analysis of the epidemiology of bovine viral diarrhea virus (BVDV) infection in dairy cattle in China. Acta tropica, 190, 296-303. doi: 10.1016/j.actatropica.2018.08.031.

Sun Jinglun, Guo Yanzhi, \& Peng Hua (2020). Analysis of China-Russia Dairy Cooperation, China Dairy Industry, 10, 21-29. (In Chinese)

Sun Yongjian (2020). Development of China's Dairy Industry in 2019, China Dairy Industry, 1, 2-5. (In Chinese)

Song Liang, \& Li Yang (2020). Four major development trends and suggestions for China’s dairy industry in 2020. Dairy and human, 1, 20-25.

Wang Dongjie (2020). Analysis of China's Dairy Industry Market in 2019 and Prospects for the Next 10 Years, Dairy Economy, 7, 48-51. (In Chinese)

Wang Dongjie (2020). Analysis of China's dairy market situation in 2019 and outlook for 2020, Agricultural Outlook, 16(1), 4-7. (In Chinese)

Wang Heng, \&Wang Zhengbing (2020). Analysis of the status and potential of Sino-Russian agricultural cooperation under the "One Belt and One Road" strategy, Anhui Agricultural Sciences, 48(14), 225-228. (In Chinese)

Wang Dian, Zhao Xianghao, \& Wang Xiaoqiong (2019). Research on the Spatio-temporal Changes of the Geographical Agglomeration of China's Dairy Industry under the Background of the Revitalization of the Dairy Industry, China Dairy Industry, 47(10), 37-40. (In Chinese)

Wei Yanjiao, \& Zhu Jing (2019). International Experience Analysis of Dairy Industry Development: Based on the Perspective of Supply Subjects. China Rural Economy, 410(02), 117-132. (In Chinese)

Yang Fengmin, \& Ding Jianjiang (2015). Problems and countermeasures in the export of Chinese agricultural products to the Russian market. Foreign Economic and Trade Practice, 3, 47-49. (In Chinese)

$\mathrm{Yu} \mathrm{Du}$ (2020). China's dairy industry rises against the market, strong demand attracts international cooperation. China's foreign trade, 11, 50-53. (In Chinese)

Zainutdinova, E.E. (2017). International comparative analysis of competition and industrial policy implementation features during the production of dairy products, International Journal of Green Pharmacy, 11(4), 5836-5842.

Tan, M., Hou Y., Zhang, L., Shi, S., Long, W, Ma, Y, Zhang, T., Li, F, \& Oenema, O. (2021). Operational costs and neglect of end-users are the main barriers to improving manure treatment in intensive livestock farms. Journal of Cleaner Production, 289(20). doi: 10.1016/j.jclepro.2020.125149.

Maitiniyazi, S., \& Canavari, M. (2021). Understanding Chinese consumers' safety perceptions of dairy products: a qualitative study, British Food Journal, Vol. ahead-of-print No. ahead-of-print. doi: 10.1108/BFJ-04-2019-0252.

Zhang Caihong \&Ren Qifang (2020). An Empirical Analysis of China’s Dairy Industry Market Performance Based on SCP Paradigm. China Forestry Economy, 3, 34-37. (In Chinese)

Zhag Zhongming, Du Nan, \& Tong Jun (2015). Prospects and real dilemmas of China's agricultural development in the Russian Far East: Based on a survey of Primorye Territory, World Agriculture, 8, 176-181. (In Chinese)

\section{Information about the author}

Qiujie Chen - Senior Researcher, Institute of Russia, Harbin Academy of Social Sciences of Heilongjiang Province (998 Shibo St., Harbin, 150028, China); e-mail: 284748191@qq.com

ARTICLE INFO: received January 12, 2021; accepted March 05, 2021

\section{Информация об авторе}

Чэнь Цюцзе - старший научный сотрудник Института России Академии общественных наук провинции Хэйлунцзян (150028, КНР, г. Харбин, ул. Шибо, 998); e-mail: 284748191@qq.com

ИНФОРМАЦИЯ О СТАТЬЕ: дата поступления 12 января 2021 г.; дата принятия к печати 5 мapma 2021 . 